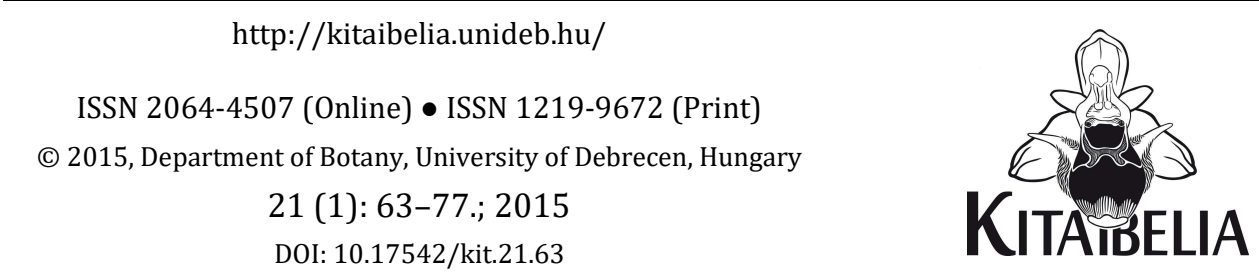

\title{
A Nyárjas-tó fitocönózisainak átalakulása
}

\author{
VAS Mihály \\ H-4324 Kállósemjén, Kossuth u. 28.; vmih@freemail.hu
}

\section{The degradation of hygrophilous plant associations of the Nyárjas Lake (E Hungary)}

\begin{abstract}
The Nyárjas Lake (located near Kállósemjén, East Hungary) was one of the most typical bogs in the Nyírség until the early 1980's. Most of its area was covered by the association of CariciMenyanthetum. The number of species characteristic to the mentioned association was generally high. As the climate became drier, hotter and were characterised by higher magnitude of extremities, the water coverage became no longer as permanent. This resulted that the Menyanthes trifoliata and Listera ovata became extinct by 2000. Lemno-Potamea species were not found after 2010. Bidentetalia, Calystegietalia, Chenopodietea and Secalietea species became more prevalent, particularly in drier periods, and locations where Carici-Menyanthetum used to be characteristic. Cirsium arvense in the mid-1990's and that of Urtica dioica in the mid-2010's became dramatically abundant. Both the number and coverage of species indicating habitat degradation have increased. The composition of wet meadow plant associations shifted towards the drier Arrhenatheretea. A moderate revitalisation of wetland associations was, however, observed coinciding years with higher precipitation.
\end{abstract}

Keywords: degradation, eutrophication, plant communities, climate change, succession

Összefoglalás - A kállósemjéni Nyárjas-tó az 1980-as évek elején még tipikus nyírségi buckaközi láp volt. Területének nagy részét eltérő tömegességi viszonyokkal jellemezhető Carici-Menyanthetum társulás borította. A karakterfajok száma magas volt. A szárazabbá, melegebbé és szélsőségesebbé váló klíma miatt az addig állandó vízborítás eleinte hónapokra, majd évekre is időszakossá vált.. Az eutrofizáció felgyorsult. Az ingadozó vízhozamú, láp mellett húzódó csatorna és a Mohos-tó számára fúrt kút vizének alkalmazása a kiszáradást csak fékezni tudta. 2000-re a Menyanthes trifoliata kipusztult. 2009-től Lemno-Potametalia fajok már nem fordultak elő. Aszályos években, különösen a korábbi Carici-Menyanthetum helyén rohamosan terjedtek a Bidentetalia, Calystegietalia, Chenopodietea és Secalietea fajok. Ezek közül az 1990-es évek közepén a Cirsium arvense, a 2010-es évek közepén az Urtica dioica tömegesen jelentkezett. A természetes állapotokra utaló fajok száma csökkent, a degradációra utalóké jelentősen nőtt. A kaszálók az Arrhenatheretea társulások irányában változnak. Az agresszív özöngyomok mellett megjelent a Pruno spinosae-Crataegetum társulás. A csapadékos években a vizes élőhelyekre jellemző cönózisok, ha kisebb mértékben, de még regenerálódtak.

Kulcsszavak: degradáció, eutrofizáció, fitocönózis, klímaváltozás, szukcesszió

\section{Bevezetés}

A nyírségi vízválasztó közelében található Nyárjas-tó szélvájta teknő alakú buckaközi mélyedése a jégkorszak végén és az újkor elején keletkezett. Az ősi folyók hordalékkúpja megemelkedett, kiszáradt és a szél formálta tovább a tájat. A buckaközi mélyedéseket a csapadékosabb időszakokban víz borította (BuLLA 1964). Bennük tavak majd lápok alakultak 
ki. A XIX. század végi lecsapolások jelentősen csökkentették a talajvízszintet. 1960-óta megfigyelhető a szélsőségesebb időjárás, a csapadék csökkenése és egyre több az aszályos év (KORMÁNY 1980). A Nyírség területén az 1970-es évek közepétől fokozatos talajvízszint csökkenés indult meg. Az 1980-as évek második felétől ez az ütem viszonylag nagy területen (elsősorban a legmagasabban elhelyezkedő részeken) felgyorsult. A tendencia az 1980-as évektől tovább erősödött (Szűcs et al. 2010). A kiszáradás enyhébb esetben az őszi aszpektusra, nagyobb aszály esetén az egész vegetációs időszakra, sőt, több évre is kiterjedt.

\section{Anyag és módszer}

A Kállósemjéntől északra, 4 km távolságban lévő Nyárjas-tóra vonatkozó részletes szakirodalmat nem találtam. A szomszédos Mohos-tóra irányult minden figyelem. A Nyárjast 1981-től kutatom. Valószínúleg a múlt század elején még általánosnak számító állandó vízborítású lápos, mocsaras hely lehetett. 1988-ban a Mohos-tóval együtt kapott védettséget. A 15,3 ha kiterjedésű terület vegetációtérképét két alkalommal, 1983-ban és 2014-ben készítettem el. Ehhez a terület 1:10 000 méretarányú EOTR térképszelvényét vettem alapul. A két vegetációtérkép jelkulcsa azonos. A vízzel érintkező partvonal 2010. 08. 10-én 130,5 mBf magasságban húzódott

1994-ben a legmélyebb mederrészben egy mérőpontot készítettem (ezt a helyet a továbbiakban tóközépnek is nevezem). Két méter mélyre nyúló perforált műanyag csövet alkalmaztam. Betonfelszíne a $0,0 \mathrm{~cm}$, az alapításkori kiszáradt talajfelszínnel egyezik. Vízborítás esetén vízmérceként, ennek hiányában talajvíz mérő helyként használom. Geokoordinátái: N 47.88814 ${ }^{\circ}$ E $21.93944^{\circ}$, tengerszint feletti magassága: 129,25 mBf (4. ábra). Később a területileg illetékes Hortobágyi Nemzeti Park Igazgatóság is állított mércét (4. ábra). Ezen a $0,0 \mathrm{~cm}$ a saját mércémen $+77,5 \mathrm{~cm}$-nek felel meg. A cönológiai táblázatban a vízállás adatok minták helyére vonatkoznak. Más esetben a vízmércémnél mért értékeket jelentik. Vízborításkor pozitív, kiszáradáskor negatív előjelűek.

A parton egy másik betonozott térképezési pontot is kialakítottam (4. ábra). Geokoordinátái: N $47.88839^{\circ}, \mathrm{E} 21.93956^{\circ}$. Erre azért volt szükség, mert a rendelkezésre álló térképekhez képest a mezei utak és kereszteződései megváltoztak. A Baromlaki (VII/4.) csatorna nyomvonala viszont jó támpontokat adott.

Cönológiai felvételeimet BRAUN-BLANQUET (1928) módszere szerint készítettem. A fajok meghatározásához HORTOBÁGYI (1968) és KIRÁLY (2009), a társulásokhoz Soó (1980) és BORHIDI \& SÁNTA (1999) műveit alkalmaztam. A cönoszisztematikai besoroláshoz és a természetvédelmi érték kategóriák számításaihoz SIMON (2000) határozóját használtam. Kvadrátjaim nádasban és magassásosban $4 \times 4$ méteresek, réteken $2 \times 2$ méteresek. A csapadékot Kállósemjénben rendszeresen mértem. A mellékelt fotók saját felvételeim. A 6. és 7. ábra fotója közel azonos helyről, a 0. pont közelében készült.

A szélsőségesebbé váló körülmények miatt fokozódott a degradáció. Ezért a határozott karakterű társulások rövid életűek, átmeneti jellegủek, biztonsággal nehezen határozhatók. Emiatt a 2014-es vegetációtérképemen és a cönológiai elemzésekben ritkábban alkalmazok konkrét társulás neveket és gyakrabban társulás felettieket. Munkámban a változásokat jobban indikáló, legmélyebb területen elhelyezkedő biotópra koncentráltam (2. táblázat).

\section{Eredmények}

A Nyárjast 1980-óta ismerem. A tömegesen virágzó vidrafüvel (Menyanthes trifoliata L.) hívta fel magára figyelmemet (5. ábra). Nádasai, rétjei is értékes fajokat rejtettek. Az egyre melegebbé és szárazabbá váló klíma, valamint a talajvíz szintjének csökkenése miatt az éves vízborítás egyre rövidebb időszakban érvényesül. A tőzeg felső rétege bomlani kezdett, tápanyagokban feldúsult. Ennek következtében a növénytakaró mára jelentősen 
megváltozott: az érzékenyebb vízi társulások eltűntek, ezzel egyidejűleg a zavarást tűrők és gyomfajok elterjedtek. A szélsőséges csapadékviszonyok miatt értékes fajokban gazdag, vizes élőhelyre jellemző társulások nem tudnak kialakulni. Ennek következtében az értékes lápi vegetáció eltűnőben van. A lápi fitocönózisok pangóvizet igényelnek. Létük a talajvíz megfelelő szintjétől, így a klímától, ezen belül elsősorban a csapadék mennyiségétől és egyenletes eloszlásától is függ. A Nyárjas vízborítottsága függ az éves csapadékösszegtől, de számít annak hónapokra lebontott mennyisége is (1. táblázat, 1. ábra).

1982-ig a csatorna egész évben rendszeresen szállított vizet, így kedvező talajvízszintet biztosított a Nyárjas-tó körül. A következő, egyre szárazabb években a VII/4-es csatornában zsilipet alkalmaztak a Mohos-tó vízellátásának javítására. A zsilip csak koratavasszal működhetett, mert belvizet okozott néhány szántón. A zsilipet 1997-ig használták, egyre csökkenő vízhozam mellett. Csapadékos években a zsilipnek köszönhetően az átlagosnál magasabb vízállás alakult ki a Nyárjason is. A tározott víz az aszályos években azonban egyre gyorsabban fogyott el. Az utóbbi évtizedekben a vízjárásban erős ingadozás tapasztalható (1. ábra). A vízellátottság szélsőségessége ártéri körülményeket teremtett. Alluviális gyomtársulás (Senecion fluviatilis R. Tx. 1950) terjedt a part mentén. A láp mocsárrá változott, majd a mocsárrétek jelentős része mezofil társulások irányába fejlődött. Mivel a csatorna mezőgazdasági területeken keresztül húzódik, vize tápanyagokat is hozott, fokozva az eutrofizálódást. A csatorna vize helyett kútvizes pótlás történt 1996-tól 2002-ig. A Mohostóval megosztott vízmennyiség kevésnek bizonyult, végül csak a Mohos-tó kapott vízpótlást. 2003-óta a Nyárjas vízborítottsága a klimatikus viszonyoktól függ.

1. táblázat. A csapadék évi összegei és havonkénti eloszlása Kállósemjénben Table 1. Yearly amount and monthly distribution of precipitation is Kállósemjén

\begin{tabular}{lcccccccccc}
\hline Év & $\mathbf{1 9 8 3}$ & $\mathbf{1 9 9 5}$ & $\mathbf{1 9 9 6}$ & $\mathbf{1 9 9 8}$ & $\mathbf{1 9 9 9}$ & $\mathbf{2 0 0 9}$ & $\mathbf{2 0 1 0}$ & $\mathbf{2 0 1 3}$ & $\mathbf{2 0 1 4}$ & $\mathbf{2 0 1 5}$ \\
\hline Január & 28,0 & 22,6 & 12,5 & 15,0 & 20,8 & 29,3 & 52,0 & 39,8 & 34,1 & 38,6 \\
\hline Február & 46,9 & 32,4 & 38,7 & 0,8 & 106,7 & 46,2 & 50,5 & 62,5 & 26,4 & 8,7 \\
\hline Március & 29,6 & 20,2 & 17,3 & 12,0 & 22,8 & 44,0 & 27,0 & 108,7 & 9,3 & 6,2 \\
\hline Április & 50,9 & 60,3 & 16,6 & 122,1 & 70,9 & 6,0 & 83,2 & 43,7 & 20,4 & 21,7 \\
\hline Május & 43,4 & 34,1 & 39,3 & 75,8 & 48,0 & 9,2 & 148,2 & 43,8 & 55,1 & 52,1 \\
\hline Június & 64,2 & 93,3 & 31,8 & 70,2 & 84,5 & 151,6 & 96,0 & 56,0 & 7,7 & 22,3 \\
\hline Július & 38,1 & 7,3 & 24,8 & 127,0 & 61,5 & 21,2 & 171,6 & 36,6 & 143,3 & 12,6 \\
\hline Augusztus & 24,2 & 91,0 & 104,8 & 57,0 & 70,4 & 22,7 & 73,1 & 17,1 & 51,9 & 40,5 \\
\hline Szeptember & 42,3 & 38,5 & 231,6 & 66,0 & 23,3 & 25,3 & 99,9 & 33,2 & 45,0 & 44,2 \\
\hline Október & 23,4 & 10,0 & 49,7 & 76,5 & 18,0 & 76,0 & 17,8 & 24,5 & 68,0 & 87,7 \\
\hline November & 50,0 & 57,1 & 7,6 & 60,2 & 77,6 & 74,8 & 58,2 & 39,9 & 14,5 & 37,2 \\
\hline December & 5,1 & 60,6 & 58,6 & 25,8 & 83,8 & 52,2 & 100,7 & 1,4 & 27,5 & 7,9 \\
\hline Összeg & $\mathbf{4 4 6 , 1}$ & $\mathbf{5 2 7 , 4}$ & $\mathbf{6 3 3 , 3}$ & $\mathbf{7 0 8 , 4}$ & $\mathbf{6 8 8 , 3}$ & $\mathbf{5 5 8 , 5}$ & $\mathbf{9 7 8 , 8}$ & $\mathbf{5 1 7 , 2}$ & $\mathbf{5 0 3 , 2}$ & $\mathbf{3 7 9 , 7}$ \\
\hline
\end{tabular}

A korábbi (1981 előtti) sok évtizedig tartó szukcessziós folyamat során a nádtőzeg vastagodásával a semlyéksásos (Carici-Menyanthetum Soó (1938) 1955) terjeszkedett. Az 1970-es években a folyamat elérte a tavi állapotban lévő legmélyebb területet is. 1981-ben ezért találkozhattam tündérrózsa hínár (Nymphaeetum albo-luteae Nowiński 1928 nymphaeetosum albae) maradványaival. A szukcesszió folyamata vázlatosan:

Lemno-Potamea

$\downarrow$

Scirpo-Phragmitetum phragmitetosum

Typhetosum latifoliae Carici-Menyanthetum

Salicetum cinereae caricetosum elatae Caricetum ripariae 
VAS (2016) - Kitaibelia 21 (1): 63-77.

2. táblázat. A fitocönózisok átalakulása a Nyárjas-tó legmélyebb területén

Table 2. Change of plant associations at the deepest part of Nyárjas lake

\begin{tabular}{|c|c|c|c|c|c|c|c|c|c|c|c|}
\hline \multirow{2}{*}{\multicolumn{2}{|c|}{ Nyárjas-tó, „tóközép” }} & \multicolumn{2}{|c|}{ 1981.07.19. } & \multicolumn{2}{|c|}{ 1983.07.30. } & \multicolumn{2}{|c|}{1987.07 .25}$. & \multicolumn{2}{|c|}{2009.08 .31}$. & \multicolumn{2}{|c|}{2014.09 .05}$. \\
\hline & & \multirow{2}{*}{\multicolumn{2}{|c|}{$\begin{array}{c}\text { A-D } \quad \text { Fr10 } \\
37-72 \mathrm{~cm}\end{array}$}} & A-D & Fr10 & A-D & Fr5 & A-D & Fr10 & A-D & Fr5 \\
\hline Vízállás - talajvíz & & & & \multicolumn{2}{|c|}{$15-35 \mathrm{~cm}$} & \multicolumn{2}{|c|}{$10-25 \mathrm{~cm}$} & \multicolumn{2}{|c|}{$-117 \mathrm{~cm}$} & \multicolumn{2}{|c|}{$-150 \mathrm{~cm}$} \\
\hline \multicolumn{2}{|l|}{ Felső gyepszint } & \multicolumn{2}{|c|}{$0-1 \%$} & \multicolumn{2}{|c|}{ 0-1\% } & \multicolumn{2}{|c|}{$0-1 \%$} & \multicolumn{2}{|c|}{$0-30 \%$} & \multicolumn{2}{|c|}{$0-2 \%$} \\
\hline \multicolumn{2}{|c|}{ Phragmites australis } & + & III & +-1 & I & + & $\mathrm{I}$ & $1-2$ & I & +-1 & III \\
\hline \multicolumn{2}{|c|}{ Schoenoplectus lacus. } & + & II & +-1 & $\mathrm{I}$ & + & $\mathrm{I}$ & \multicolumn{2}{|c|}{ - } & \multicolumn{2}{|c|}{-} \\
\hline \multicolumn{2}{|l|}{ Typha latifolia } & + & II & +-1 & I & + & I & $1-3$ & $\mathrm{~V}$ & + & II \\
\hline Alsó gyepszint & & $55-$ & $5 \%$ & $75-$ & $2 \%$ & 55 & $2 \%$ & 92 & $8 \%$ & 95-9 & $8 \%$ \\
\hline Carex elata & & $2-4$ & $\mathrm{~V}$ & $2-4$ & $\mathrm{~V}$ & $3-4$ & $\mathrm{~V}$ & +-2 & II & + & I \\
\hline Menyanthes trifol & & $2-4$ & $\mathrm{~V}$ & $2-4$ & $\mathrm{~V}$ & 1 & $\mathrm{~V}$ & & ste & - & \\
\hline Sparganium erec & & $1-2$ & $\mathrm{~V}$ & + & $\mathrm{I}$ & 1 & $\mathrm{~V}$ & +-1 & III & - & \\
\hline Oenanthe aquatic & & + & III & + & II & $1-3$ & $\mathrm{~V}$ & $1-3$ & $\mathrm{~V}$ & 1 & II \\
\hline Equisetum fluviat & & + & $\mathrm{I}$ & & & & & & & - & \\
\hline Equisetum palust & & + & $\mathrm{I}$ & + & $\mathrm{I}$ & & & & 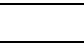 & - & \\
\hline Galium palustre & & + & I & + & III & + & II & +-1 & IV & $1-2$ & IV \\
\hline Rorippa amphibic & & & & + & $\mathrm{I}$ & 1 & $\mathrm{~V}$ & +-1 & III & $1-3$ & $\mathrm{~V}$ \\
\hline Lycopus europaet & & & & + & $\mathrm{I}$ & + & II & +-1 & $\mathrm{~V}$ & - & \\
\hline Agrostis stolonife & & & & + & $\mathrm{I}$ & + & $\mathrm{I}$ & & & - & \\
\hline Persicaria amphi & & & & + & $\mathrm{I}$ & + & $\mathrm{I}$ & & & - & \\
\hline Cicuta virosa & & & & & & + & $\mathrm{I}$ & & 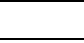 & - & \\
\hline Solanum dulcamc & & & & & & & & $1-5$ & $\mathrm{~V}$ & - & \\
\hline Rumex palustris & & & & & & & & +-2 & $\mathrm{~V}$ & 1 & IV \\
\hline Persicaria lapath & & & & & & & & +-3 & IV & - & \\
\hline Bidens tripartita & & & & & & & & +-1 & II & + & $\mathrm{I}$ \\
\hline Urtica dioica & & & & & & & & & & $2-5$ & $\mathrm{~V}$ \\
\hline Myosoton aquatic & & & & & & & & & & $1-2$ & $\mathrm{~V}$ \\
\hline Cirsium arvense & & & & & & & & & & 1 & $\mathrm{~V}$ \\
\hline Epilobium tetrag & um & & & & & & & & 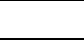 & +-1 & III \\
\hline Phytolacca ameri & & & & & & & & & & 1 & II \\
\hline Conyza canadens & & & 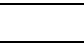 & & & & & & 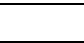 & +-1 & II \\
\hline Nymphaeion & & $2-$ & $0 \%$ & & $0 \%$ & & $\%$ & & & - & \\
\hline Nymphaea alba & & $1-2$ & V & +-2 & V & $2-3$ & V & & t & - & \\
\hline Lemnetea & & $4-2$ & $2 \%$ & & $\%$ & & & & 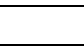 & - & \\
\hline Lemna trisulca & & $1-2$ & V & +-2 & V & + & II & & 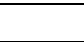 & - & \\
\hline Utricularia vulga & & 1 & $\mathrm{~V}$ & $1-2$ & $\mathrm{~V}$ & 1 & $\mathrm{~V}$ & & 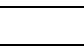 & - & \\
\hline Riccia fluitans & & + & I & +-1 & V & + & I & & t & - & \\
\hline Ceratophyllum su & nersum & +-1 & IV & +-2 & IV & & & & 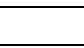 & - & \\
\hline Nitella mucronat & & +-1 & II & + & I & & & & 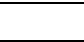 & - & \\
\hline Ceratophyllum de & ersum & + & I & & & & & & 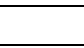 & - & \\
\hline Lemna minor & & + & $\mathrm{I}$ & + & I & + & $\mathrm{I}$ & & 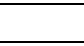 & - & \\
\hline Spirodela polyrhi & & + & $\mathrm{I}$ & & & & & & & - & \\
\hline Al & 2009 & $\begin{array}{l}\text { Abuti } \\
\text { palus } \\
\text { Lythr } \\
\text { Setar }\end{array}$ & $\begin{array}{l}\text { on theo } \\
\text { ris, Che } \\
\text { m salic } \\
\text { a pumil }\end{array}$ & $\begin{array}{l}\text { hrasti } \\
\text { opodi } \\
\text { ria, } M \\
\text { Xant }\end{array}$ & $\begin{array}{l}\text { Ambros } \\
\text { n rubr } \\
\text { ntha ac } \\
\text { um str }\end{array}$ & $\begin{array}{l}\text { a arte } \\
\text { m, Cyp } \\
\text { uatica } \\
\text { mariu }\end{array}$ & $\begin{array}{l}\text { sia, } B \\
\text { us fus } \\
\text { anunc }\end{array}$ & $\begin{array}{l}\text { omus } \\
\text { Is, Ech } \\
\text { lus sce }\end{array}$ & $\begin{array}{l}\text { mbella } \\
\text { nocysti } \\
\text { eratus, }\end{array}$ & $\begin{array}{l}\text { Is, Calth } \\
\text { lobata, } \\
\text { alix cine }\end{array}$ & rea \\
\hline Аксіuеns тајок & 2014 & $\begin{array}{l}\text { Alope } \\
\text { C. pol } \\
\text { apari } \\
\text { Salix }\end{array}$ & $\begin{array}{l}\text { urus a } \\
\text { sperm } \\
\text { e, Lact } \\
\text { inerea, }\end{array}$ & $\begin{array}{l}\text { qualis, } \\
n, \text { Ech } \\
\text { ca ser } \\
\text { etario }\end{array}$ & $\begin{array}{l}\text { rctium } \\
\text { ochloa } \\
\text { ola, Lyt } \\
\text { oumila }\end{array}$ & $\begin{array}{l}\text { appa, } \\
\text { crus-g } \\
\text { rum s }\end{array}$ & $\begin{array}{l}\text { Irex ri } \\
\text { Echir } \\
\text { caria, }\end{array}$ & $\begin{array}{l}\text { aria, } \\
\text { cystis } \\
\text { nopor }\end{array}$ & $\begin{array}{l}\text { enopoc } \\
\text { obata, } \\
\text { lium ac }\end{array}$ & $\begin{array}{l}\text { um albu } \\
\text { alium } \\
\text { nthium }\end{array}$ & \\
\hline
\end{tabular}


Az első cönológiai felvételezés és a vegetációtérképezés idején még csak Soó (1980) művét használhattam. A cönotaxon neveket ezért az 1983-as vegetációtérképen meghagytam.

A Carici-Menyanthetum elnevezés jobban tükrözi a Nyárjas-tó társulását, mint a Carici pseudocyperi-Menyanthetum Soó 1955, amit BoRHIDI \& SÁNTA (1999) alkalmaz. A szomszédos Mohos-tó ingólápjának szegélyén és az ingólápban található semlyékek szélén valóban Carex pseudocyperus L. között fejlődik a Menyanthes trifoliata L., a Nyárjason azoban a C. pseudocyperus nem fordult elő. Itt zsombéksás (Carex elata All.) alkotott semlyéksásos társulást.

1981 tavaszán a legmélyebb $1500 \mathrm{~m}^{2}$-es területen (tóközépen) a tavaszi maximális vízmélység 95-115 cm-es volt. A vidrafü populáció teljes életciklusú, jól fejlett egyedekből állt. A magas, vastag, dús üstökű, más fajoknak is otthont adó zsombéksás oszlopok változatos méretű, 4-50 m²-es vízfelületeket határoltak. Ezekben a semlyékekben többnyire a vidrafü borítása dominált, de tündérrózsa (Nymphaea alba L.) mindenhol előfordult bennük (5. ábra), nagyobb semlyékekben akár önállóan is (VAS 1982). Felszíni lebegőhínár a Lemno-Utricularietum vulgaris Soó 1928 és Ceratophylletum submersi (Soó) Den Hartog et Segal 1964 volt. Kis területen előfordult a fénycsillárkás (Nitello-Ceratophylletum submersi Borhidi et al. 1998) is. A zsombéksás, vidrafú és a tündérrózsa a gyékényesben (Typhetum latifoliae G. Lang 1973) és a nádasban (Phragmitetum communis Soó 1927 Schmale 1939) is előfordult, de az árnyékolás miatt háttérbe szorult (VAS 1984).

1983-ban az első vegetációtérkép (3. ábra) készítésének idején, tavasszal a korábbi években megismert társulások még nem mutattak degradációs tüneteket, mivel a csatorna duzzasztása 1983 nyarának közepéig vízborítást biztosított az aszályos nyár ellenére. Az előző évek magasabb vízállásának hatására a legmélyebb területen, a Carici-Menyathetum tipikus társulásában erősödött a Riccia fluitans L., Utricularia vulgaris L. és a Ceratophyllum submersum L. borítása, míg a Phragmitetea fajoké csökkent. A vidrafü, zsombéksás és a tündérrózsa állapota nem változott jelentősen. A zsombékfejekben gyakoribbá vált a Galium palustre L., a semlyékekben pedig a Riccia fluitans. Helyenként Persicaria amphibia (L.) S. F. Gray keveredett Menyanthes trifoliata-val. Ugyanúgy kúszva, legyökerezve, úszó levelekkel és kiemelkedő virágzattal. Augusztus közepére az élőhely kiszáradt. A nagyobb, napégette semlyékekben a vidrafü súlyosan károsodott, amit fokozott a tél, mert takarás és vízborítás hiányában a vadkár és a fagykár is jobban érvényesült.

A szomszédos zónában, főleg déli irányban, sekélyebb vízben, a Carici-Menyanthetum Soó 1955 typhetosum latifoliae-ban, erősödött a felső gyepszint. Ez a vidrafü, a zsombéksás és a tündérrózsa virágzási hajlamát csökkentette ugyan, de borítási és előfordulási értékeit nem. Kisebb foltokban előfordult a Typhetum latifoliae G. Lang 1973, fejletlen alsó gyepszinttel és fajgazdag, jelentős borítású lebegőhínárral. A Typhetum angustifoliae (Soó 1927) Pignatti 1953 magassásos jellegű fajgazdagabb társulás volt. Az itt készült, alább látható felvételben (és a továbbiakban is) zárójelben az arab számjegyek az A-D, a római számok a Fr értéket jelentik:

1983. 07. 28-án: Typha angustifolia (3 V), T. latifolia (+-1 III), Phragmites australis (+-1 IV), Carex acutiformis (1-2 V), C. elata (1-2 IV), Scutellaria galericulata (+ IV), Menyanthes trifoliata (1-4 III), Sparganium erectum (+ III), Oenanthe aquatica (+ II), Galium palustre (+ II), Lycopus europaeus (+ II), Lythrum salicaria (+ II), Nymphaea alba (1-2 III), Lemna trisulca (1-2 V), Riccia fluitans (+ IV), Lemna minor (+-1 III), Utricularia vulgaris (1 II). Akcidens fajok: Agrostis stolonifera, Carex disticha, C. riparia, Equisetum palustre, Mentha aquatica, Rorippa amphibia, Spirodela polyrhiza. Az észak-keleti partközeli területen a Caricetum acutiformis-ripariae Soó 1930 társulásba zárva két helyen Equiseto limosi-Caricetum rostratae Zumphe 1929. (A vegetáció térképen Caricetum rostratae). Fajösszetétele a névadó faj, a csőrös sás (Carex rostrata Stokes) előfordulásán kívül nem különbözött lényegesen a környező társulásokétól. Jelentősebb borítású és frekvenciájú fajai 1-3 cm magas vízborításnál: Sparganium erectum (3 V), Carex rostrata (3 V), C. acutiformis (2 V), C. elata (1-2 IV). 
A következő, gyakrabban szárazra kerülő zónát a Phragmitetum communis magnocaricosum társulást a nád uralta, de vidrafü is előfordult tündérrózsával és Lemnetea fajokkal. (A vegetációtérképen Scirpo-Pragmitetum magnocaricosum.)

Feltűnő volt a Carex acutiformis terjedése. Az őszi aszpektusban a vízborítás nélküli, de nedves talajfelszínen helyenként fejlett mohaszint alakult ki. Déli szélein a Bolboschoenus maritimus (L.) Palla és Shoenoplectus tabernaemontani (C. C. Gmel.) Palla kisebb állományai szikesedést jeleztek. Külső zónája mocsárréti fajokban gazdagabb volt, viszonylag sok indifferens faj kíséretében. A Nymphaea alba előfordulása a Carici-Menyanthetum, CariciMenyanthetum typhetosum és Phragmitetum communis magnocaricosum társulásokban az 1980 előtti évtizedek csapadékosabb időjárását tanúsítja.

Caricetum acutiformis-ripariae Soó (1927) 1930 társulás belső, mélyebb zónájában még gyakoriak voltak a Phragmitetea fajok. A Magnocaricion elatae-ra jellemzők közül a zsombéksás. Külső zónáját Magnocaricion elatae és Molinio-Juncetea fajok határozták meg. Előfordult benne Orchis elegans Heuff (+ II). Akcidensként előforduló ritkaságok: Cicuta virosa és Cirsium brachycephalum. Az alsó gyepszintben a Nyárjas É-i és D-i részén szórványosan fiatal Salix cinerea L. egyedek jelentek meg.

A mocsárrétek jelentős részét régebben szántással bolygatták. A nád és a cserjék terjedését a vizsgált időszakban rendszeres kaszálás fékezte. Alsó zónájukat tavasszal víz látogatta. A kaszált területeken Caricetum acutiformis-ripariae, Caricetum distichae Steffen 1931 és Agrostio-Caricetum distantis Rapaics ex Soó 1938 mozaikok fordultak elő. A kaszálók legnagyobb kiterjedésú és fajgazdagságú társulása (68faj) a Cirsio cani-Festucetum praetensis Májovsky et Ruzičková volt. Jelentős borítású konstans fajaik: Calystegia sepium, Equisetum palustre, Festuca pratensis, Lycopus europaeus, Mentha aquatica, M. longifolia, Poa pratensis, P. trivialis, Potentilla anserina. Akcidensként előforduló ritkaságok: Cirsium brachycephalum és Listera ovata. A társulásban, főleg a déli területen Angelica sylvestris és Centaurea jacea subsp. angustifolia alkotott kiterjedt facieseket. A magasabban fekvő zónában az Arrhenatheretea fajok gyakoribbá váltak (VAS 1984).

1984-ben a Carici-Menyanthetum semlyékjeiben még előfordult szórványos vidrafú virágzás. Az árasztás lehetőségei a következő években csökkentek. Néhány csapadékos év kivételével a tendencia a kiszáradás felé haladt.

1985-ben a kiszáradó semlyékeket feltúrták a vaddisznók. Pusztították a tündérrózsát és a vidrafüvet. Ezután csak a gyékény és a nád védelmében fordultak elő néhány évig. A vidrafü szórványos előfordulása a zsombékfejekre korlátozódott. Az üresen maradt helyért megindult a versengés. Tavasszal Ranunculus trichophyllus, nyáron Oenanthe aquatica és Rorippa amphibia uralta a semlyékeket Nymphaea alba társaságában. Akcidensként, de előfordult termést érlelő Cicuta virosa is.

1986-ban a Nyárjas keleti oldalát, ami eddig szántóterület volt, fehér nyárral telepítették be. A talaj előkészítése során a szomszédos rétet több helyen bolygatták és területének jelentős részét fásították. Ezzel az érintett társulások degradációja felgyorsult.

1987-ben az előző évek kedvező kora tavaszi árasztási lehetőségei miatt a legmélyebb területen megerősödött a zsombéksás és a tündérrózsa. A semlyékekbe, ha kis borítási értékkel is, de visszatért vidrafü (2. táblázat). A Carici-Menyathetum typhetosum-ban nőtt a gyepszint borítása, főleg a Phragmitetea fajok erősödésével. A vidrafú itt jól átvészelte az aszályos időszakot, de a felső gyepszint növekvő árnyékoló hatása nem kedvezett a virágzásnak. A Phragmitetum communis-ban szintén sűrűbbé vált a felső szint. Csökkent a Magnocaricion elatae fajok részesedése, a vidrafü csak egy mintában, legyengült példányként fordult elő. A tündérrózsa kipusztult. A Lemnetea fajok borítása visszaesett, de gyakoribbá vált benne a Riccia fluitans és megjelent a Ricciocarpus natans. A nádszegélyben, magassásosokban és nedves rétszakaszokon Angelica sylvestris, Calystegia sepium, a szárazabb zónában Pastinaca sativa subsp. pratensis, Achillea collina és Daucus carota 
borítása fokozódott. Az északi oldalon a nádas szegélyében 12 db 1,5-2 m magas Salix cinerea bokrot számoltam. Ezzel a láp cserjésedése elkezdődött.

Csapadékszegény időszak következett, az árasztás lehetősége csökkent. A vidrafü a tipikus élőhelyén már csak szórványosan fordult elő.

1988 júliusában semlyékek kiszáradtak. Szórványos volt a vidrafű és a tündérrózsa előfordulása.

1989 áprilisában lehetőség volt egy kismértékű árasztásra a VII/4 csatornából. A Nyárjason a vízborítás $40 \mathrm{~cm}$ volt.

1990 júniusában a terület ismét kiszáradt. A semlyékekben a vidrafü szórványosan, legyengülve, de a zsombékfejekben még jó állapotban fordult elő. Feltűnő volt a Rorippa amphibia tömeges megjelenése.

1992 júniusában kéthetes, kismértékű árasztásra volt lehetőség. A vidrafü főleg a tóközép környéki nádasban és gyékényesben fordult elő.

1993 áprilisában ismét kismértékủ vízpótlásra volt lehetőség a csatornából.

1994-ben a jellemző vízállások: 05. 01-én: -2 cm, 09. 13-án: -161 cm. Tavasszal Rorippa amphibia és Ranunculus trichophyllus dominált. Vidrafü és fehér tündérrózsa csak szórványosan fordult elő. Nyár végéig a Cirsium arvense elözönlötte a területet.

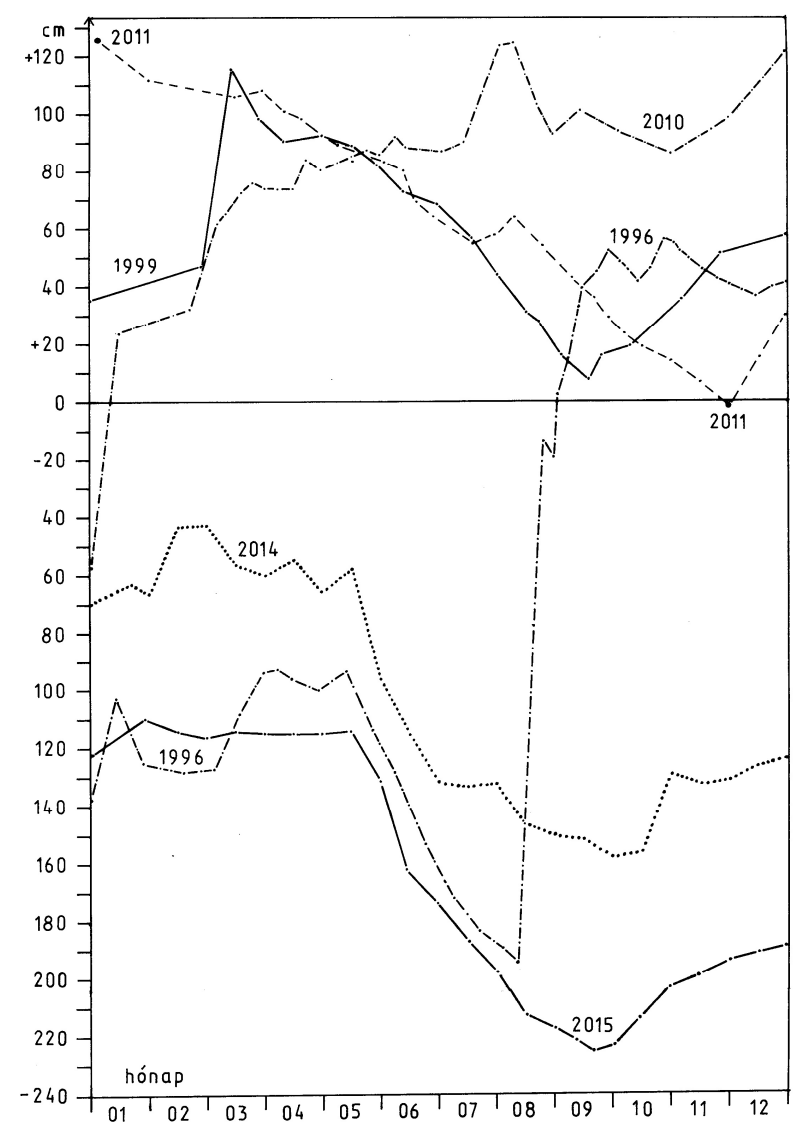

1. ábra. Vízszintváltozások a Nyárjas-tó legmélyebb területén

Fig. 1. Water level changes in the deepest part of Nyárjas lake 1995-ben a jellemző vízállások: 04. 23-án: $-112 \mathrm{~cm}, 09$. 3-án: $-168 \mathrm{~cm}$. Tavasszal a területet Rorippa amphibia dominancia jellemezte. A Menyanthes trifoliata a semlyékekből eltűnt, csak a zsombékfejekben található, kis borítási értékkel. Nyáron a domináns fajok: Cirsium arvense és Chenopodium album. A Nymphaea alba minden társulásból kipusztult és később sem mutatkozott.

1996-ban a jellemző vízállások: 04. 28-án: $-100 \mathrm{~cm}, 09$. 15-én: +40 cm. Áprilisban a Nyárjas 80\%-a leégett. A zsombéksás és a benne meghúzódó vidrafü nem károsodott jelentősen. Nyár végén a bőséges csapadék hatására jelentős vízborítás alakult ki. Ezt 20 napig a kút is támogatta a VII/4-es csatorna mellett (1. ábra). A vidrafü az 1983-as tipikus területéről kiszorult.

1997-ben a jellemző vízállások: 05. 06-án: +34,5 cm, 09. 06-án: -17,5 cm. A vidrafü populáció a számára eddig menedékadó gyékényesben és nádasban is csökkent.

1998-ban jellemző vízállások: 05 . 02-án: +58 cm, 09. 04-én: $+15,5$ cm. A tartós vízborítás következtében, a Typha latifolia és Sparganium erectum uralta a legmélyebb területet. A 
zsombéksás tovább gyengült a vidrafü pedig innen és a gyékényesből is kipusztult. Csak az északnyugati terület nádas szegélyében találtam egy 180 hajtásból álló populációt.

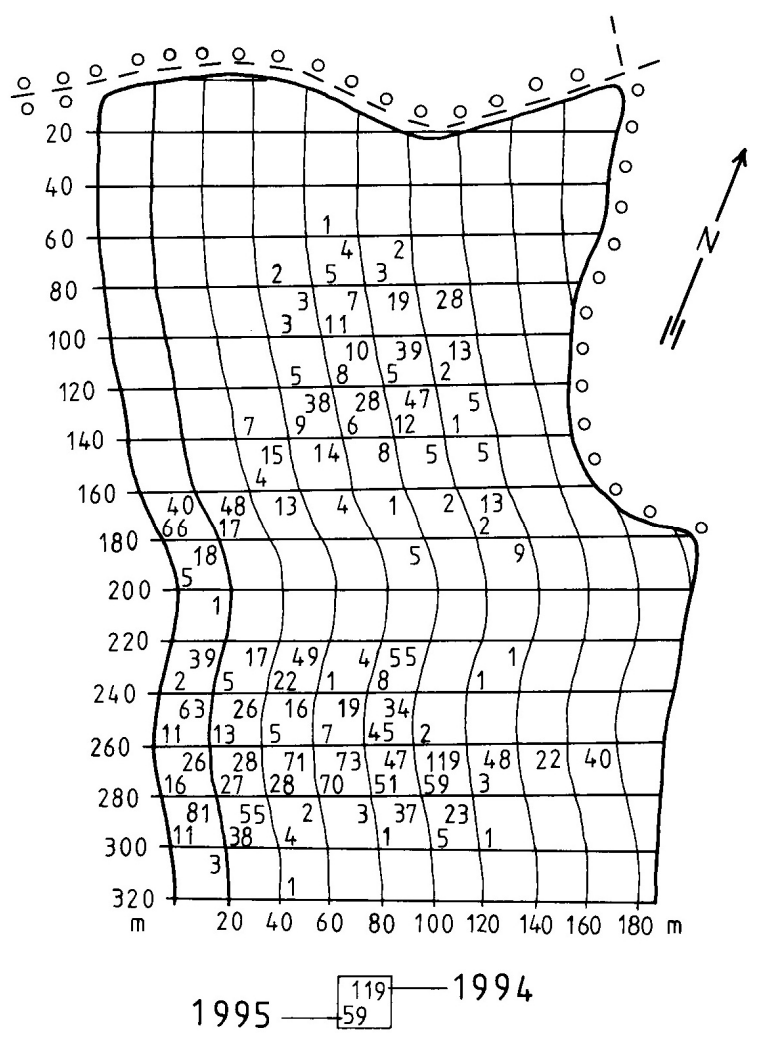

2. ábra. A Menyanthes trifoliata hajtásszámok 1994-ben és 1995-ben

Fig. 2. Number of Menyanthes trifoliata shoots in 1994 and 1995
(A vidrafü egyedszámát a kúszva elágazó és legyökerező elágazó hajtásrendszere miatt nem lehet meghatározni. Ezért hajtásszámot közlök.) Becslésem szerint 1983-ban a Nyárjas vidrafü populációját közel 60 000 db-os hajtásszám jellemezhette. Későbbi felméréseim során 1994-ben 1937 db, 1995-ben 814 db, 1998-ban 180 db hajtást találtam (2. ábra). Terjed a Salix cinerea. Az északi oldalon 16 egyed, a D-i oldalon, főleg a csatorna közelében 6 egyed képviselte a terjedő bokorfüzest. Az északi oldalon $9 \mathrm{db}$ magyar kőrist (Fraxinus angustifolia Vahl. subsp. danubialis Pouzar) ültettem a partvonalon (A 0 . pont mellett).

1999-ben a jellemző vízállások: 03. 14-én: $+116,5 \mathrm{~cm}, 05$. 01-én: $+93 \mathrm{~cm}$, 09. 04-én: $+16 \mathrm{~cm}$. Őszre a maradék vidrafü is kipusztult. Ezután évekig próbálkoztam visszatelepítéssel, de a nyáron rendszeresen kiszáradó semlyékekbe özönlő Bidentetea tripartitae, Calystegietalia, Chenopodietea és Secalietea fajok erős konkurensnek bizonyultak.

2000-ben a jellemző vízállások: 04 . 29-én: +91,5 cm, 09. 03-án +13,5 cm. A csatorna vize mellett a kút is segített fenntartani a kedvező állapotot. A rétek jelentős része június elejéig tartós vízborítást kapott. A legmélyebb területen erősödött a zsombéksás, a semlyékeket Typha latifolia és Lemnetea fajok borították. Július 10-én a következő cönózis jellemezte:

Typha latifolia (2-4 V), Carex elata (2-3 V), Sparganium erectum (+-1 V), Rumex palustris (1-2 III) Oenanthe aquatica (+ III), Rorippa amphibia (+-1 III), Bidens tripartitus (+ I), Galium palustre (+ I), Lycopus europaeus (+ I), Ranunculus sceleratus L. (+ I), Scutellaria galericulata (+ I), Ceratophyllum submersum (3-4 V), Lemna minor (+-1 III), Ricciocarpus natans (+ II).

2001-ben a jellemző vízállások: 05. 04-én: $+59 \mathrm{~cm}, 08$. 21-én: $+30 \mathrm{~cm}$. A kút egész évben üzemelt. Kis mértékben a csatorna vize is segített. A Carex elata populációja a 1980-as évek óta jelentősen csökkent. Fejlett egyedekből álló társulás csak az északkeleti partszegély 100 m-es szakaszán és a délnyugati kaszálórét mentén voltak. Ez utóbbi a legnagyobb területű (300-350 $\mathrm{m}^{2}$ ). Augusztus 21-én, a tóközépi területen az előző évi holt és az azévi élő gyékény borítása összesen 65-70\%-os volt, így jelentős árnyékoló hatást fejtett ki. A megmaradt zsombékokon szórványosan Scutellaria galericulata, Rorippa amphibia, Galium palustre, a semlyékekben Lemna minor, Lemna trisulca fordult elő.

A 2002-2005 közötti állapotról nincs jelentős adatom. 2002-ben erdősávot telepítettek a nyugati oldalon, amit 2004-ben újabb 30 m-el szélesítettek. Főleg kocsányos tölgyet ültettek, 
de később ennek D-i része a vadkár miatt Pruno spinosae-Crataegetum Soó 1927 cserjéssé változott.

2006. 08. 21-én a saját vízmércémnél $+63,5 \mathrm{~cm}$-es a vízborítás. A víz sötétbarna, átlátszó volt, de Lemnetea fajok csak nyomokban fordultak elö. A Typha latifolia borítása $10-15 \%$. Az előző évben valószínúleg Solanum dulcamara özönlötte el a területet, mert csupasz indái sűrűn behálózták a víz alatti teret. A gyékényre kapaszkodott egyedek viszont virágoztak és termést érleltek.

2007 augusztusára a terület kiszáradt. A talajvízszint $-57,5 \mathrm{~cm}$.

2008-ban a jellemző vízállások: 04. 04-én: $+20 \mathrm{~cm}, 09$. 08-án: $-114 \mathrm{~cm}$. A tóközépen a következő fajok alkottak társulást:

Solanum dulcamara (1-5 V), Cirsium arvense (1-4 V), Lycopus europaeus (1-2 V), Rumex palustris $(1-2 \quad$ V), Galium palustre (+-1 V), Oenanthe aquatica ( $+-1 \quad$ V), Rorippa amphibia $(+-1 \quad$ V), Urtica dioica L. (+-1 V), Conyza canadensis (+-1 III), Persicaria maculosa (+-1 III), Lythrum salicaria (1 II), Mentha aquatica (+-1 II), Myosoton aquaticum (+-1 II), Lactuca serriola (+ II), Alopecurus aequalis (1 I), Bidens tripartitus (1 I), Carex elata (1 I), Calystegia sepium (+ I), Sonchus arvensis (+ I).

2009-ben a jellemző vízállások: 04. 30-án: $+67,5 \mathrm{~cm}, 09$. 10-én: $-125,0 \mathrm{~cm}$. 05. 05-én a vízfelszínt tömegesen borították az Oenanthe aquatica és a Rumex palustris csíranövényei. Szórványosan fordult elő a Lemna gibba, Lemna minor, Lemna trisulca és Ricciocarpus natans. 07. 05-én a lebegőhínárban (Lemnetum gibbae Miyavaki \& J.TX. 1960) a Lemna gibba (1-5 V) több mintában 80-90\%-os borítást ért el. Július közepétől a vízborítás megszunnt. Október elejére a talajvízszint $-140 \mathrm{~cm}$-re süllyedt. A nyárvégi aszpektusban, (borításban és frekvencia értékben) a Calystegietalia (Solanum dulcamara) dominált, de jelentős volt a Phragmitetea, Magnocaricion elatae és Bidentetea tripartitae fajok részesedése is. A gyomok terjedtek (2. táblázat). A kiszáradást követően a vaddisznók túrásai főleg a Carex elata visszatérését akadályozták. A Menyanthes trifoliata telepítéseket is elpusztították.

2010-ben a jellemző vízállások: 04. 29-én: $+80 \mathrm{~cm}, 09$. 13-án: +101,5 cm. A kiemelkedően csapadékos évben ( $979 \mathrm{~mm} /$ év) a vízborítás végig magas volt. Ennek következtében az előző évi szegély- és gyomtársulások összeomlottak. Lemnetea társulások nélküli, 10-15\%-os Typha latifolia borítású szabad felszínú víztér alakult ki.

2011-ben a jellemző vízállások: 05 . 10-én: $+88,5 \mathrm{~cm}, 09$. 11-én: $+43,5 \mathrm{~cm}$. A víz sötétbarna és átlátszó. Októberig kialakult borítási értékek: Typha latifolia 75-85\%, Sparganium erectum 1-7\%, Solanum dulcamara 0,5-3\%. Persicaria amphibia 3-5\%. A Lemnetea társulások továbbra is hiányoztak. (Az utóbbi két évben a récék száma jelentős volt!)

2012-ben a jellemző vízállások: 05. 01-én: $+39 \mathrm{~cm}$, 09. 15-én: $-118 \mathrm{~cm}$. Ebben a csapadékszegény évben a legmélyebb terület június végére kiszáradt. Nyár végére a Typha latifolia sarjadása lelassult, de az elszáradt, még álló, előző évi növényekkel együtt jelentősen árnyékolták az alsó gyepszintet. Az augusztus 25-én készült felvételben a Solanum dulcamara (1-2 III), Urtica dioica (1 III), Rorippa amphibia juv. (+-1 III), Rumex palustris juv. (+-2 III), Sparganium erectum (+-1 II) értékeket mutatott. Jelentős volt a vaddisznók által feltúrt, csupasszá változott terület.

2013-ban a jellemző vízállások: 04. 30-án: +94,5 cm, 09. 30-án: -81cm. A csapadékos télvégi és tavaszi időszak miatt augusztusig kedvezőek a vízviszonyok. Ennek ellenére a Typha latifolia továbbra is kis borítású. A hosszú aszályos időszak kiszárította a biotópot. Az alsó gyepszintben ősszel már a Rorippa amphibia, Rumex palustris és Oenanthe aquatica juvenilis példányainak borítása dominált. Ismét megjelent a Carex elata, de vadkár áldozataivá vált. Az Urtica dioica borítása még elszórtan, de növekvő foltokban jelentkezett. 


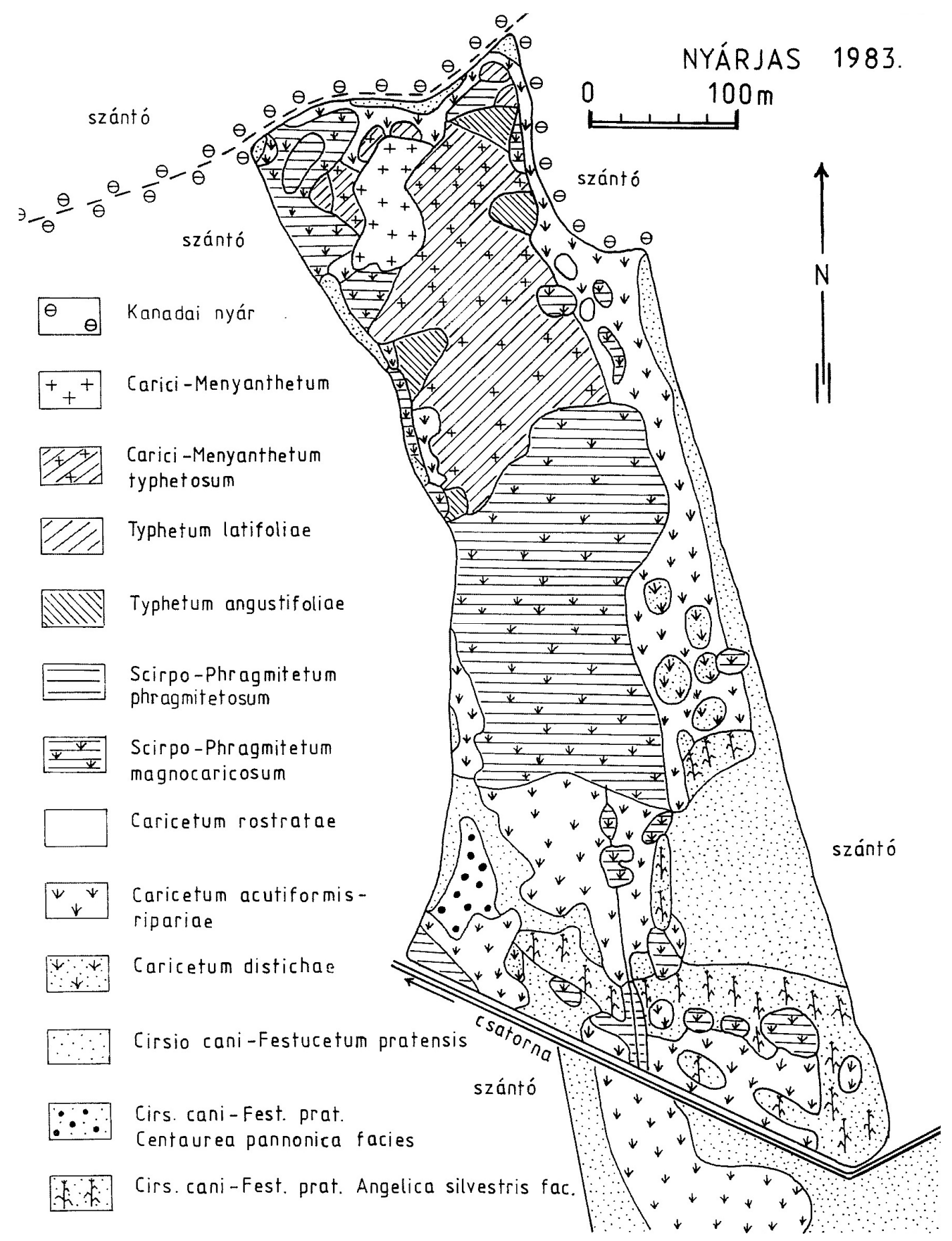

3. ábra. A kállósemjéni Nyárjas-tó vegetációtérképe 1983-ban

Fig. 3. Vegetation map of Nyárjas lake in 1983 


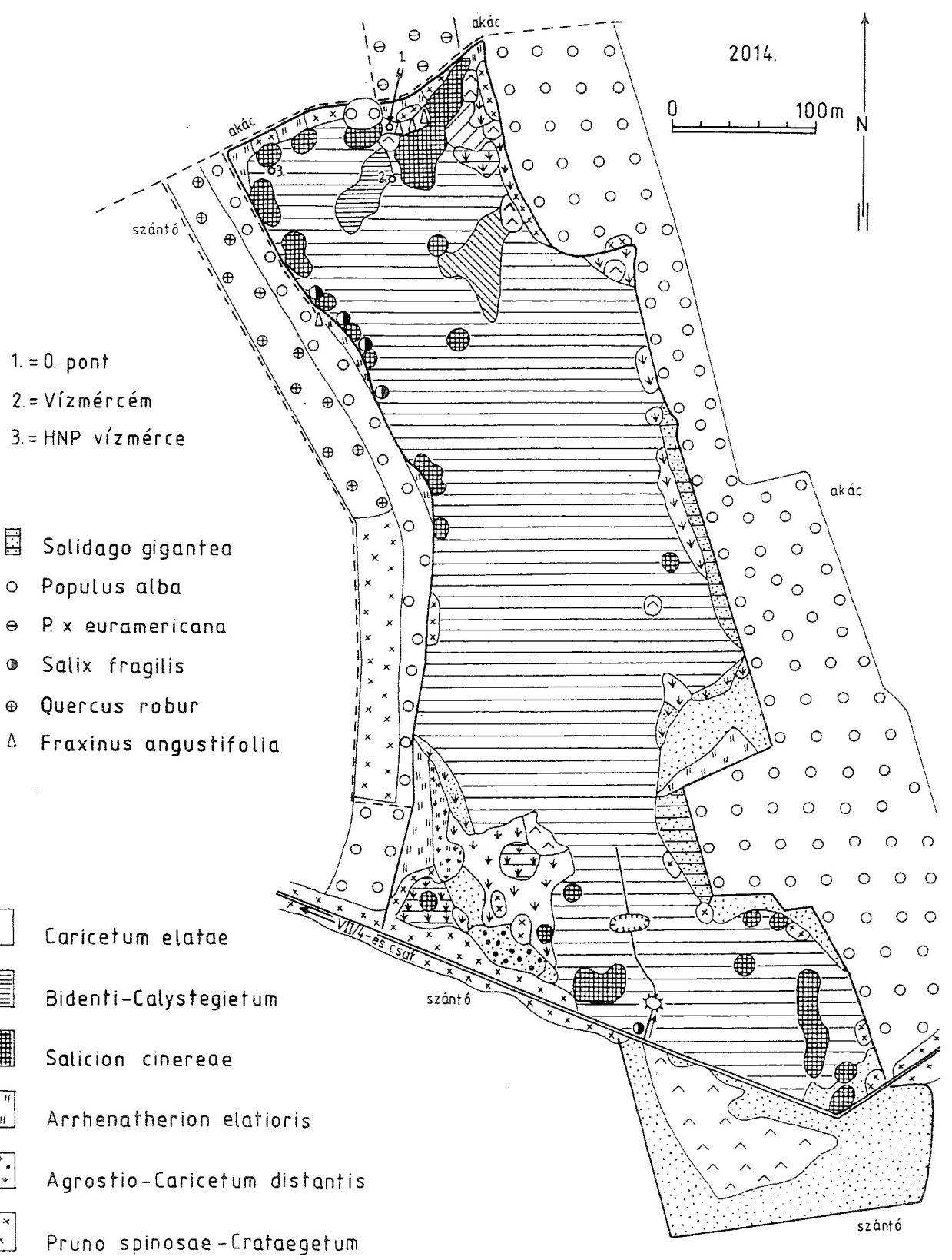

4. ábra. A kállósemjéni Nyárjas-tó vegetációtérképe 2014-ben

Fig. 4. Vegetation map of Nyárjas lake in 2014

2014-ben a jellemző vízállások: 05. 01-én: -65cm, 09. 15-én: -151,5 cm. A Nyárjasról cönológiai felvételeim alapján újabb vegetációtérképet készítettem (4. ábra). A csapadékhiány miatt a terület egész évben száraz volt. A talajvíz tovább csökkent, a kiemelkedően csapadékos július (143 mm!) ellenére. Június 06-án az élőhelyet borító növényzet domináns 
fajai: Rumex palustris (3-4 V) 61\%-os borítási átlaggal, Oenanthe aquatica (2 V) 11,5\%-os borítási átlaggal, Rorippa amphibia (1-2 V) 9\%-os borítási átlaggal, Myosoton aquaticum (12 V), Galium palustre (1-2 V), Urtica dioica (1 IV). Akcidens fajok: Apera spica-venti, Ambrosia artemisia, Arctium lappa, Bromus sterilis, Galium aparine, Poa trivialis, Persicaria lapathifolia, Vicia cracca és Vici sativa. A tavasszal Oenantho aquaticae-Rorippetum amphibiae (Soó 1928) Lohm. cönózis 1950 őszre Urtica dioica dominálta BidentiCalystegietum Felföldy 1943 társulássá alakult (2. táblázat). Az Urtica dioica a minták összesítésében átlagosan 63\%-os, a Rorippa amphibia 19\%-os borítású. A 27 fajból 12 faj Chenopodietea és Secalietea faj, 4\%-os borítási átlaggal. A degradációra utaló fajok csoportrészesedése a két felvételben hasonló, 58\% illetve 54,5\%. A Phragmitetea fajok csoportrészesedése $25 \%$ illetve $23 \%$.

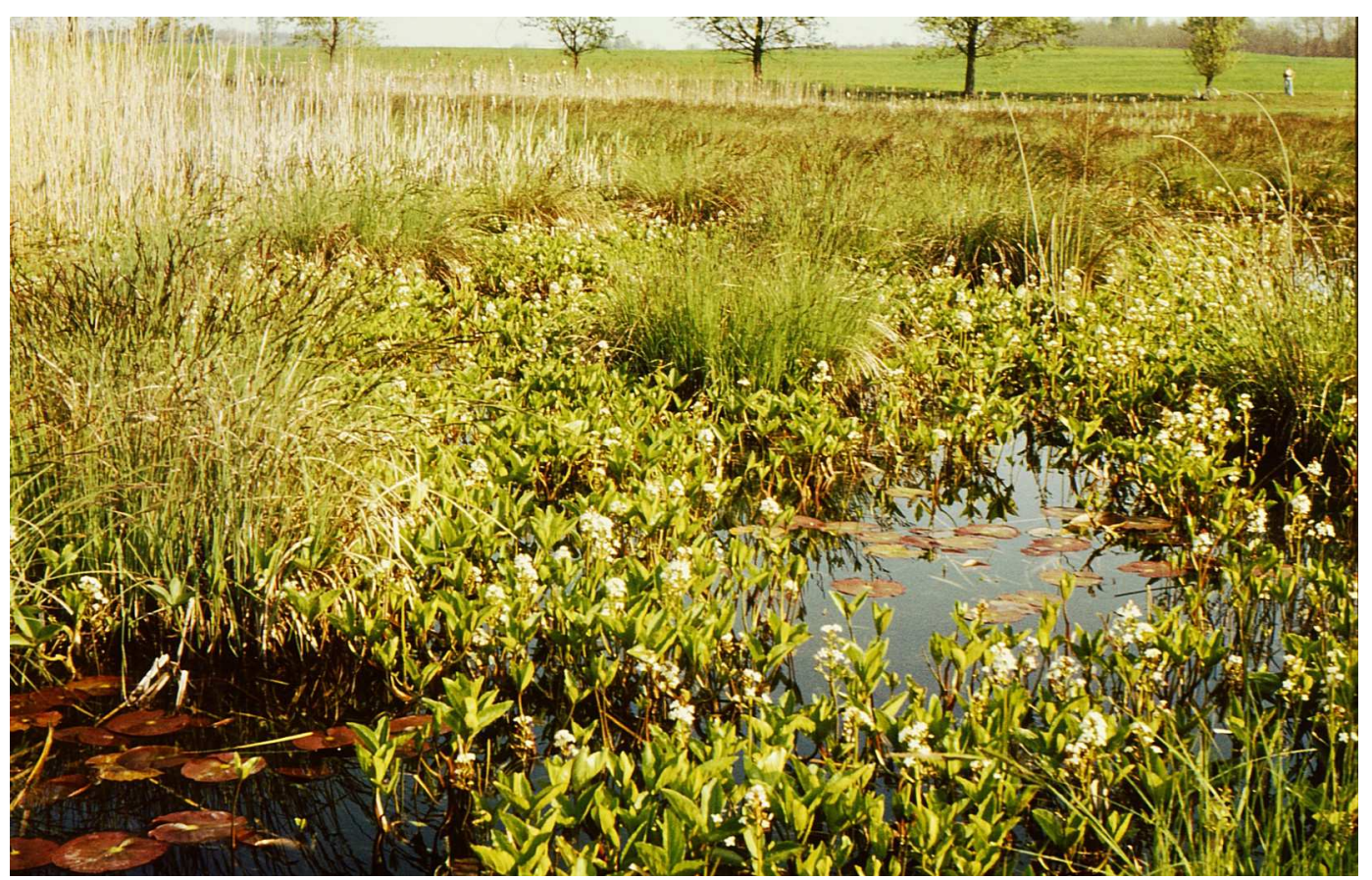

5. ábra. Carici-Menyanthetum társulás 1982-ben

Fig. 5. The Carici-Menyanthetum association in 1982

A többi cönózis is jelentősen megváltozott a 35 év során. 2014-re a Scirpo-Phragmitetum phragmitetosum alsó gyepszintjének fajszáma és borítása egyaránt csökkent. Az 5-30 m széles szegélyzóna kivételével gyakorlatilag alsó szint nélküli, sok avas nádat tartalmazó, sűrű egyfajú társulás lett. Főleg a déli harmadában Calystegia sepium borította, de terjedt a Solanum dulcamara is. Megjelent az Echinocystis lobata és a Humulus lupulus. A degradációra utaló fajok 27\%-ot képviseltek. A Nyárjas északi harmadában gyakoriak voltak a vaddisznók által rendszeres túrással, dagonyázással kialakított 30-250 $\mathrm{m}^{2}$-es tisztások.

A Caricetum elatae maradványai jelentősen degradálódtak. A nádszegély mentén, főleg annak délnyugati részén fordulnak elő. Itt található a néhány tíz egyedre zsugorodott Cirsium brachycephalum populáció. A zsombéksásos csoportrészesedése: Phragmitetea: 21\%, Molinetalia és Arrhenatheretalia: 15\%, Chenopodietea és Secalietea: 10,5\%, Calystegietalia: 10,5\%, Magnocaricion elatae: 8,5\%, Bidentetea tripartitae: 6\%. Ebből a degradációra utaló fajok 30\%-ot értek el. Az utóbbi évtizedben a VII/4-es csatornától délre, a réten kialakult egy 
fiatal Caricetum elatae társulás. A kedvezőtlen időben történő kaszálások és a száraz évek miatt azonban karakterfajokban szegény volt.

A Caricetum acutiformis-ripariae területe gyakrabban és hosszabb időre került szárazra. Mivel az ezt a társulást alkotó fajok sűrủbben borították a felszínt, mint a semlyékekkel tarkított zsombéksásost, a gyomfajok nehezebben terjedtek benne. Szélső zónáikban, főleg a déli területen, viszont hódított a Crataegus monogyna és a Prunus spinosa. A Caricetum distichae társulásban a névadó faj 90-95\%-os borításával eredményesen fékezte más társulások fajainak támadását.

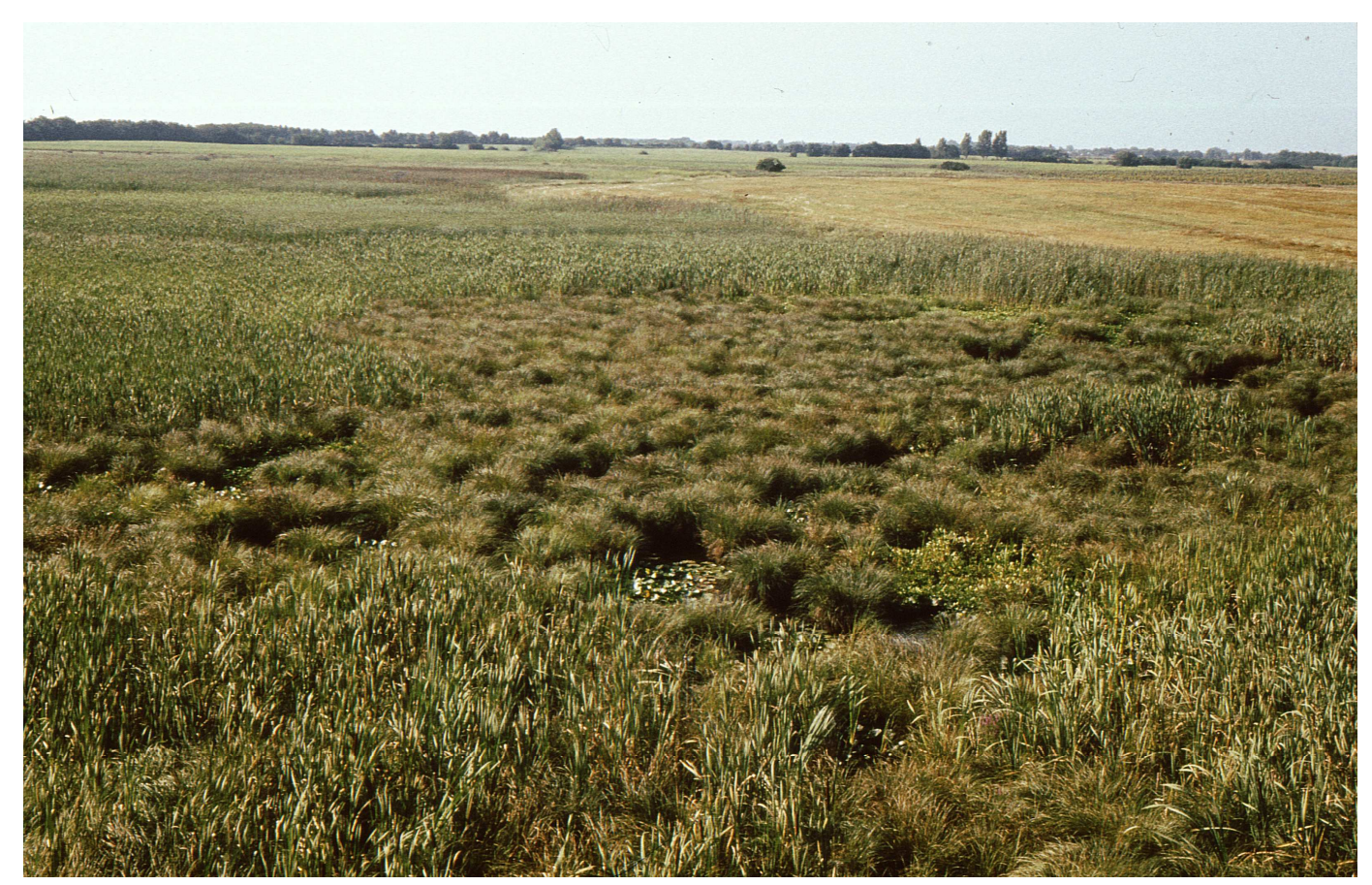

6. ábra. A Nyárjas-tó 1982-ben

Fig. 6. The Nyárjas lake in 1982

Korábban a Molinietalia aszociációsorozatba tartoztak a kaszálók rétjei. A Cirsio caniFestucetum pratensis társulásban és annak korábbi facieseiben mára jelentős változások történtek. A karakter fajok borítása és frekvenciája csökkent. Az átalakulás a PastinacoArrhenatheretum (Knapp 1954) Passarge 1964 társulás irányába történik, főleg a magasabb térszinteken. A kiszáradás a szélsőséges hatások és a kaszálások időnkénti kimaradása miatt a társulások nem stabilak. Ezt tükrözik a cönológiai felméréseim eredményeiből számított természetvédelmi érték-kategóriák adatai, melyekben a degradációra utaló fajok száma 7080\%! A külső szélek felől terjed a Solidago gigantea és az Asclepias syriaca. Megjelentek a cserjék is (Crataegus monogyna, Prunus spinosa, Rosa canina). Legjobb állapotban a csatornától délre eső rét van a rendszeres kaszálás és a jobb időszakos vízellátás miatt. A Nyárjas-tó északi és déli végén, a nádasban Salicion cinereae asszociáció-csoporthoz tartozó társulás is degradálódik.

2015-ben a jellemző vízállások: 04. 30-án: -115 cm, 09. 20-án: -226 cm, Aszályos tavasz után aszályos nyár következett. A terület talajvízszintje eddig nem tapasztalt mértékben tovább csökkent. A felső tőzegréteg gyorsuló lebomlására az ökoszisztéma erőteljes Urtica dioica invázióval válaszolt. Ez különösen a legmélyebb területen és környékén érvényesült. Május 6-án már döntően ez az egy faj uralta a területet (7. ábra). Ugyanekkor ennek $80 \mathrm{~m}^{2}$ - 
es, nedvesebb részét a Rorippa amphibia $62 \%$, Cirsium arvense 15\%, Myosoton aquaticum $3 \%$, Urtica dioica $2 \%$ és Alopecurus aequalis 1\%-os értékkel borította. Hasonló összetétel jellemezte a nádasban a vaddisznók túrásaival és dagonyáival létrejött tisztásokat is. Ősszel az 1983-ban még Carici-Menyanthetum társulás teljes területén az Urtica dioica állomány 200-230 cm-es magasságot és 95-100\%-os borítást ért el. Más fajok itt csak szórványosan fordultak elö.

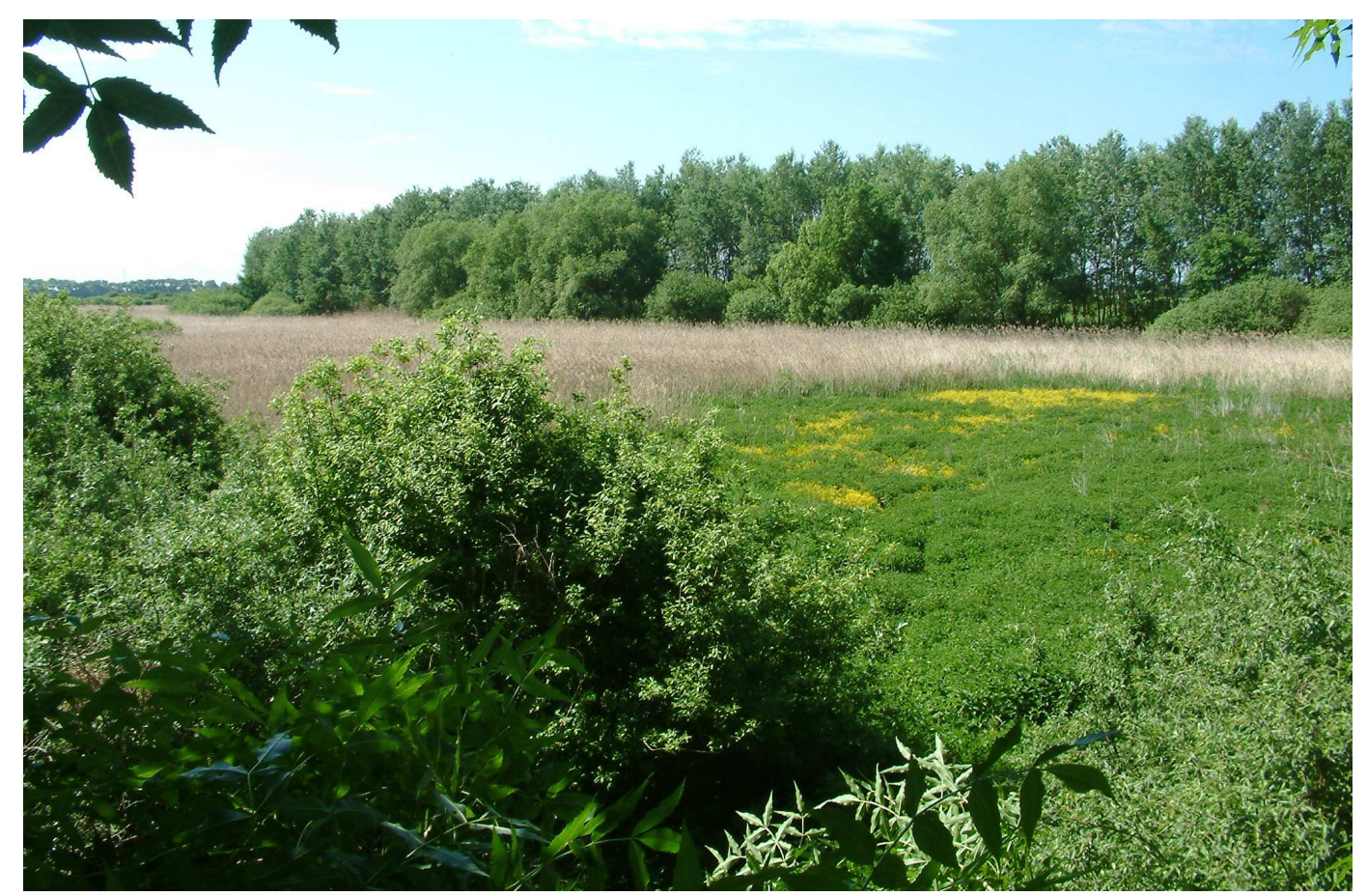

7. ábra. A Nyárjas-tó 2015-ben

Fig. 7. The Nyárjas lake in 2015

1983. óta a klíma szárazabbá, melegebbé válása, a csapadékjárás kiszámíthatatlansága és a talajvíz szintjének egyre mélyebbre szállása megszüntették az egyenletes pangóvizes körülményeket. A lápi társulások összeomlottak. Az egyre rövidebb időszakos vízborítás a mocsári növényeknek kedvezett. A tóközépen, a Carici-Menyanthetum helyén, vízborítástól függően Hydrocharietalia, Rorippo-Oenanthetum, Bidenti-Calystegietum társulásai jelentek meg. A vízborítás nélküli években az eutrofizálódás fokozódása miatt a Chenopodietea és Secalietea fajok is inváziószerűen terjedtek.

A Phragmitetum communis keleti szegélyén és a déli felén tovább növekedett a Calystegia sepium által árnyékolt terület. A meggyengült Phragmites australis emiatt 30-50 m-es foltokban sok helyen összeroskadt. Nyár végére a hosszú aszályos időszak miatt a Calystegia sepium takaró nagy része elszáradt. Árnyékolás hiányában a megritkult nádasban ősszel terjedt az Urtica dioica. Molinietalia, Chenopodietea és Secalietea fajok jelentek meg. A Caricetum elatae társulás tovább gyengült. Főleg a Cirsium arvense és Calystegia sepium inváziója miatt. A Cirsio cani-Festucetum pratensis társulások területén a Cirsium arvense, Solidago gigantea és Vicia cracca borítása tovább nőtt. A Pastinaco-Arrhenatheretum-ban Asclepias syriaca, Solidago gigantea és Erigeron annuus terjedt. A kaszálás elmaradása miatt a Crataegus monogyna és Prunus spinosa gyakoribb lett. 


\section{Köszönetnyilvánítás}

Köszönettel tartozom Lesku Balázsnak és Szigetvári Csabának az angol nyelvű fordításokért. Köszönöm Takács Attilának a kézirat javításával kapcsolatos hasznos tanácsait.

\section{Irodalom}

BORHIDI A. \& SÁNTA A. (szerk.) (1999): Vörös könyv Magyarország növénytársulásairól 1-2. - TermészetBÚVÁR Alapítvány Kiadó, Budapest.

BRAUn-BlanqueT J. (1928): Pflanzensoziologie. - Berlin.

Bulla B. (1964): Magyarország természeti földrajza. - Tankönyvkiadó, Budapest, pp. 92-95.

HoRToвágY T. (1968): Növényhatározó. Baktériumok-Mohák. - Tankönyvkiadó, Budapest, p. 189., pp. 571-573.

KIRÁLY G. (szerk.) (2009): Új magyar füvészkönyv. Magyarország hajtásos növényei. Határozókulcsok. Aggteleki Nemzeti Park Igazgatóság, Jósvafő.

KoRMÁNy Gy. (1980): Nyíregyháza éghajlata. - Bessenyei György Tanárképző Főiskola Tudományos Közleményei, Földrajz, Nyíregyháza, pp. 75-94.

Simon T. (2000): A magyarországi edényes flóra határozója. Harasztok-virágos növények. - Nemzeti Tankönyvkiadó, Budapest, pp. 838-955.

Soó R. (1980): A magyar flóra és vegetáció rendszertani-növényföldrajzi kézikönyve VI. - Akadémia Kiadó, Budapest, pp. 525-538.

SZÛ́CS P., MADARÁSZ T., SZÁNTó J., ZÁKÁNYI B. \& GoNDA N. (2010): A kállósemjéni Nagymohos vízháztartási viszonyainak meghatározása hidrodinamikai modellezés, illetve terepi monitoring vizsgálatok segítségével. - Miskolci Egyetem Környezetgazdálkodási Intézet, Miskolc, pp. 14.

VAS M. (1982): Carici-Menyanthetum - Vidrafüves a kállósemjéni Nyáriason - Botanikai Közlemények 70 (1-2): 37-39.

VAS M. (1984): A kállósemjéni Nagymohos és Nyárjas fitocönológiája, természetvédelmi helyzete. Doktori értekezés, József Attila Tudományegyetem Természettudományi Kar, Növénytani Tanszék, Szeged, pp. 80-100.

Beérkezett / received: 2015. 11. 11. • Elfogadva / accepted: 2016. 03. 15. 